\title{
Pengaruh Pengembangan Sumber Daya Manusia dan Disiplin Kerja terhadap Kinerja Pegawai (Studi pada Bagian Umum dan Hukum Tata Laksana Universitas Brawijaya)
}

\author{
Maria Lusianita ${ }^{a^{*}}$ \\ a Universitas Brawijaya, Kota Malang, Jawa Timur, Indonesia
}

\section{INFORMASI ARTIKEL}

\section{Article history:}

Dikirim tanggal: 06 Mei 2020

Revisi pertama tanggal: 26 Maret 2021

Diterima tanggal: 29 Maret 2021

Tersedia online tanggal: 15 April 2021

Keywords: Human Resource

Development, work discipline, employee performance

\begin{abstract}
Employees in an agency need to be managed professionally in order to achieve a balance between the needs of employees and the guidance untill their capabilities of the agency. Organizations benefit from operational continuity with increased performance, while employees feel they have a greater commitment to the organization. In line with the phenomenon of human resource development, employee work discipline must also be developed. This study aims to explain the impact of human resource development and work discipline on non-PNS employees and employees. The results of the study state that the development of human resources on employee performance shows a positive but insignificant effect, besides that the effect of work discipline on employee performance shows a positive and significant effect. In addition, the moderating effects of age, work status, and years of service also do not have a significant effect.
\end{abstract}

\section{INTISARI}

Pegawai yang ada didalam suatu instansi perlu dikelola secara profesional agar terwujud keseimbangan antara kebutuhan pegawai dengan tuntunan dan kemampuan instansi tersebut. Organisasi memperoleh manfaat dari kelanjutan operasional dengan kinerja yang meningkat, sementara para pegawai merasa memiliki komitmen lebih besar kepada organisasi. Sejalan dengan fenomena pengembangan sumber daya manusia, disiplin kerja karyawan juga harus dikembangkan. Penelitian ini bertujuan untuk menjelaskan dampak pengembangan sumber daya manusia dan disiplin kerja pada pegawai non-PNS dan pegawai. Hasil dari penelitian menyatakan bahwa perkembangan sumber daya manusia terhadap kinerja pegawai menunjukkan pengaruh positif akan tetapi tidak signifikan. Selain itu pengaruh disiplin kerja terhadap kinerja pegawai menunjukkan pengaruh positif dan signifikan. Selain itu efek moderasi usia, status kerja, dan masa kerja juga tidak berpengaruh secara signifikan.

2021 FIA UB. All rights reserved.

\section{Pendahuluan}

Dalam era globalisasi sekarang ini sumber daya manusia memiliki peranan penting dalam setiap kegiatan organisasi. Meskipun didalam organisasi tersedia sarana dan prasarana yang berlebihan tanpa didukung sumberdaya yang andal tidak dapat menyelesaikan kegiatan organisasi dengan baik. Keberhasilan organisasi

\footnotetext{
* Corresponding author. Tel.: +62-899-0309-123; e-mail: niet4_christoper@yahoo.co.id
} 
dalam mencapai tujuan dan berbagai sasaran serta kemampuan menghadapi berbagai tantangan, baik yang bersifat eksternal maupun internal, sangat ditentukan oleh kemampuan mengelola sumber daya manusia dengan setepat-tepatnya (Siagian 2006, h. 3). Tuntutan organisasi untuk memperoleh, mengembangkan, dan mempertahankan sumber daya manusia yang berkualitas semakin mendesak sesuai dengan dinamika lingkungan yang selalu berubah.

Untuk mencapai visi dan misi suatu organisasi atau instansi, pimpinan dituntut menyediakan sumber daya manusia yang berkualitas supaya dalam menjalankan tugas pokok dan fungsinya mencapai hasil yang optimal dan bermanfaat, maka usaha-usaha yang harus dilakukan adalah mengikutsertakan pegawainya untuk mengikuti pendidikan dan pelatihan. Pengelolaan pegawai secara profesional ini harus dimulai sejak perekrutan pegawai, penyeleksian, pengklasifikasian, penempatan pegawai, penataran, dan pengembangan karir, seperti yang dikemukakan Mangkunegara (2007). Ini berarti seorang pegawai yang ada dalam instansi tersebut secara proporsional harus diberikan latihan dan pendidikan yang sebaik-baiknya, bahkan harus sesempurna mungkin.

Sejalan dengan pertumbuhan kebutuhan pendidikan tinggi, maka perkembangan perguruan tinggi selalu menjadi perhatian masyarakat. Mengacu pada Undangundang Republik Indonesia Nomor 12 Tahun 2012 tentang Pendidikan Tinggi; disebutkan bahwa tujuan dari pendidikan tinggi tidak hanya dilihat sebagai pusat ilmu pengetahuan, pusat penelitian, dan pusat pengabdian kepada masyarakat, tetapi juga suatu penghasil ilmu pengetahuan yang perlu bersaing untuk menjamin kelangsungan hidup. Kedudukan para personel pendidikan, memiliki peran masing-masing sesuai dengan kedudukan dan fungsinya. Satu sama lain melengkapi, tidak ada yang menduduki posisi yang dominan dalam berkontribusi pada usaha pencapaian tujuan pendidikan.

Dalam suatu instansi perguruan tinggi istilah sumber daya manusia tersebut sering kita artikan sebagai tenaga pendidik yang berarti dosen dan tenaga kependidikan yang berarti pegawai adminstrasi, dan salah satunya adalah Universitas Brawijaya. Prestasi yang diraih Universitas Brawijaya selain didukung oleh kualitas mahasiswa dan kualitas dosen, juga didukung oleh faktor yang tidak kalah penting, yaitu kualitas pegawai.

Organisasi memperoleh manfaat dari kelanjutan operasional dengan kinerja yang meningkat, sementara para pegawai merasa memiliki komitmen lebih besar kepada organisasi. Salah satu wujud nyata dalam hal pengembangan pegawai dibidang pendidikan tinggi adalah diadakannya pendidikan dan pelatihan fungsional untuk memenuhi persyaratan yang sesuai dengan jenis dan jenjang jabatan fungsional, yang ditetapkan oleh instansi pembina jabatan fungsional bersangkutan.
Sejalan dengan fenomena pengembangan sumber daya manusia, disiplin kerja pegawai juga perlu dikembangkan, karena manajer menggunakannya untuk berkomunikasi dengan karyawan, sehingga mereka bersedia melakuka perubahan perilaku, serta upaya peningkatan kesadaran dan kesediaan orang tersebut untuk tunduk pada aturan organisasi dan norma sosial yang berlaku (Rivai, 2008, h. 824). Sementara itu, Hasibuan (2016, h. 193) berpendapat, bahwa kedisiplinan adalah "kesadaran serta kesediaan seseorang untuk menaati segala peraturan organisasi dan norma-norma sosial yang berlaku."

Kemudian, Hasibuan (2016, h. 202) juga menyatakan bahwa "kepuasan kerja adalah sikap emosional yang menyenangkan dan mencintai pekerjaannya. Sikap ini dicerminkan dari moral kerja, kedisplinan, dan prestasi kerja". Artinya ketika seluruh tenaga kependidikan Universitas Brawijaya jelas status kepegawaiannya, maka akan berdampak pula pada kepuasan kinerja mereka yang dicerminkan dengan memaksimalkan kinerja mereka demi meningkatkan kinerja Universitas Brawijaya. Jika mereka cinta pada pekerjaannya maka apapun status kepegawaiannya tidak akan mempenga-ruhi kinerjanya.

Berdasarkan latar belakang diatas, peneliti mengajukan konsep penelitian ini yang diharapkan dapat mengetahui seberapa besar pengaruh pengembangan sumber daya manusia dan disiplin kerja terhadap kinerja tenaga kependidikan Non-PNS dan kontrak serta dapat mengatasi permasalahan-permasalahan yang terjadi. Sehingga penulis mengambil judul "Pengaruh Pengembangan Sumber Daya Manusia dan Disiplin Kerja Terhadap Kinerja Pegawai (Studi pada Bagian Umum dan Hukum Tata Laksana Universitas Brawijaya)".

\section{Teori}

\subsection{Manajemen Sumber Daya Manusia}

Dalam bukunya, Hasibuan (1999, h. 10) berpendapat bahwa "Manajemen sumber daya manusia adalah ilmu dan seni mengatur hubungan dan peranan tenaga kerja agar efektif dan efisien membantu terwujudnya tujuan perusahaan, karyawan dan masyarakat".

Menurut Ndraha (1999, h. 52) definisi manajemen sumber daya manusia adalah "Perencanaan, pengorganisasian, penggunaan (penggerakan), dan penilaian SDM sedemikian rupa, sehingga SDM memberikan kontribusi sebesar-besarnya kepada masyarakat (makro) dan organiasi (mikro)".

Kemudian, Sinambela (2014, h. 68) menyatakan definisi manajemen sumber daya manusia adalah "Pengelolaan sumber daya manusia sebagai sumber daya atau asset yang utama, melalui penerapan fungsi 
manajemen maupun fungsi operasional sehingga tujuan organisasi yang telah ditetapkan dapat tercapai dengan baik".

Berdasarkan definisi dari manajemen sumber daya manusia yang telah dikemukakan oleh beberapa ahli, maka kesimpulannya adalah manajemen SDM merupakan metode pengelolaan hubungan dan peran sumber daya (tenaga kerja) yang efektif dan efisien yang dimiliki oleh ilmu pengetahuan atau individu dan dapat digunakan dengan cara yang paling optimal untuk mencapai hasil yang maksimal bersama perusahaan, karyawan dan masyarakat.

\subsection{Pengembangan Sumber Daya Manusia}

Pendapat Mathis \& Jackson (2006, h. 350) pengembangan sumber daya manusia adalah "Pengembangan (development) mewakili usaha-usaha meningkatkan kemampuan para karyawan untuk menangani beraneka tugas dan untuk meningkatkan kapabilitas diluar kapabilitas yang dibutuhkan oleh pekerjaan saat ini". Sementara itu, menurut Hasibuan (2016, h. 69) pengembangan sumber daya manusia adalah "Suatu usaha untuk meningkatkan kemampuan teknis, teoritis, konseptual, dan moral karyawan sesuai dengan kebutuhan pekerjaan atau jabatan melalui pendidikan dan pelatihan". Sedangkan Rowley \& Jackson (2012, h. 88) mengungkapkan bahwa pengembangan sumber daya manusia diartikan sebagai "Sebuah proses yang dilakukan untuk mengembangkan pengetahuan, keahlian, dan kemampuan pekerja".

Pengembangan staf merupakan kegiatan yang harus dilakukan oleh perusahaan agar pengetahuan, keterampilan, dan kemampuannya relevan dengan persyaratan pekerjaan yang mereka lakukan. Pengembangan sumber daya manusia jangka panjang yang berbeda dengan pelatihan untuk suatu jabatan khusus makin bertambah penting bagi bagian personalia. Pengembangan sumber daya manusia bagi pegawai adalah suatu proses belajar dan berlatih secara sistematis untuk meningkatkan kompetensi kinerja mereka dalam pekerjaannya sekarang dan menyiapkan diri untuk peran dan tanggung jawab yang akan datang.

Pada Universitas Brawijaya perubahan status kepegawaian merupakan salah satu upaya rektor dalam pengembangan sumber daya manusia (tenaga kependidikan). Pengembangan Tenaga Kependidikan pada Universitas Brawijaya dapat berupa pemberian pendidikan dan pelatihan sesuai dengan yang diperlukan dalam menunjang kelancaran pekerjaan sehari-hari. Selain itu, terdapat cara lain dalam hal pengembangan tenaga kependidikan, yaitu pengangkatan pegawai kontrak yang menjadi pegawai tetap Non-PNS Universitas Brawijaya sesuai peraturan rektor yang telah di tentukan.
Menurut Hasibuan (2016, h. 83) yang menjadi indikator dalam mengukur metode pengembangan, antara lain sebagai berikut:

a) Prestasi kerja karyawan

Jika prestasi kerja atau efisiensi kerja, kualitas maupun kuantitas pekerjaan meningkat setelah karyawan berpartisipasi dalam pengembangan, maka metode perbaikan diterapkan dengan baik. Namun demikian, kinerja bisnis yang stabil berarti metode perbaikannya kurang baik, sehingga diperlukan perbaikan.

b) Kedisiplinan karyawan

Jika disiplin karyawan diperkuat setelah mengikuti pengembangan berarti metode pengembangan yang dilaksanakan baik. Namun jika kontrol tidak meningkat berarti metode pengembangan yang dilaksanakan kurang baik.

c) Absensi karyawan

Jika ketidakhadiran karyawan berkurang setelah mengikuti pengembangan berarti metode yang digunakan sudah baik, namun jika karyawan berhalangan berarti metode pengembangan saat tidak baik.

d) Tingkat kerusakan produksi, alat, dan mesin-mesin Jika kerusakan produksi, peralatan, dan mesin karyawan berkurang setelah pengembangan, berarti metode pengembangannya baik. Namun jika itu berarti metode pengembangannya masih kurang baik.

e) Tingkat kecelakaan karyawan

Setelah mengikuti program pengembangan, tingkat kecelakaan karyawan harus berkurang. Jika tidak berkurang, maka cara pengembangannya kurang baik dan perlu perbaikan.

f) Tingkat pemborosan bahan baku, tenaga, dan waktu Jika tingkat pemborosan bahan baku, tenaga, dan waktu berkurang berarti proses pengembangannya baik. Disisi lain, jika masih, maka metode pengembangan yang digunakan kurang baik.

g) Tingkat kerja sama

Tingkat kerja sama para karyawan harus lebih harmonis, harmonis, dan lebih baik setelah mengikuti perkembangan.

h) Tingkat upah intensif karyawan

Jika upah intensif karyawan meningkat, berarti metode pengembangannya bagus. Namun, jika tetap berarti metode pengembangan aplikasinya kurang baik.

i) Prakarsa karyawan

Prakarsa/ inisiatif karyawan harus ditingkatkan setelah metode pengembangan yang diterapkan tidak membaik atau tetap berarti metode pengembangan yang diterapkan kurang baik. Diharapkan karyawan mampu bekerja secara mandiri dan mampu mengembangkan kreatifitasnya sendiri. 
j) Kepemimpinan dan Keputusan Manajer

Kepemimpinan dan keputusan yang diambil manajer setelah pelaksanaan pengembangan harus ditingkatkan, kerjasama yang harmonis, tujuan tercapai, stres berkurang, dan kepuasan karyawan ditingkatkan. Jika mendapatkan hal diatas, berarti pendekatan pengembangan yang diterapkan sudah baik.

\subsection{Disiplin Kerja}

Menurut Hasibuan (2016, h. 193) kedisiplinan adalah "Fungsi operatif manajemen sumber daya manusia yang terpenting karena semakin baik disiplin pegawai semakin tinggi prestasi kerja yang dapat dicapainya. Tanpa disiplin yang baik, sulit bagi organisasi maupun instansi mencapai hasil yang optimal". Adapun definisi disiplin kerja menurut Sastrohadiwiryo (2003, h. 291) adalah "Suatu sikap menghormati, menghargai, patuh dan taat terhadap peraturan-peraturan yang berlaku, baik yang tertulis maupun tidak tertulis serta sanggup menjalankannya dan tidak menggelak untuk menerima sanksi-sanksinya apabila ia melanggar tugas dan wewenang yang diberikan kepadanya". Sementara menurut Rivai (2008, h. 824), kedisiplinan adalah "Fungsi operatif manajemen sumber daya manusia yang terpenting, karena semakin baik disiplin karyawan pada perusahaan, maka semakin tinggi prestasi kerja yang dapat dicapai".

Disiplin adalah sikap dan tingkah laku serta perbuatan yang berdasarkan dengan peraturan yang ada di instansi secara tertulis yang tidak tertulis. Disiplin yang baik mencerminkan rasa tanggung jawab seseorang atas pekerjaan yang dipercayakan kepadanya. Hal ini menambah kinerja, semangat kerja, dan terwujudnya tujuan instansi, pegawai, dan masyarakat. Oleh karena itu, setiap pimpinan kerja selalu berusaha agar para bawahannya mempunyai tingkat disiplin yang baik. Seorang pemimpin dikatakan efektif dalam kepemimpinannya, apabila para bawahannya berdisiplin baik. Disiplin juga merupakan kesadaran dan kesiapan seseorang untuk mematuhi semua aturan di suatu instansi yang dibuat manajemen yang mengingat anggotainstansi agar dapat dijalankan semua pegawai baik dengan kesadaran sendiri maupun dengan paksaan.

Hasibuan (2016, h. 195) mengemukakan indikator disiplin kerja diantaranya, sebagai berikut:

a) Tujuan dan Kemampuan

Tujuan dan keterampilan juga mempengaruhi kedisiplinan karyawan. Tujuan yang dicapai harus didefinisikan dengan jelas, ideal, dan bijaksana untuk pengembangan staf.

b) Teladan Pimpinan

Dalam mendefinisikan etos kerja karyawan, manajer dimanfaatkan oleh bawahannya sebagai panutan dan panutan. Pemimpin harus memberi contoh yang baik, sopan, jujur, dan adil dalam tindakannya. Para pemimpin hendaknya tidak mengharapkan sopan santun dari bawahannya jika mereka sendiri tidak jujur secara moral.

c) Balas Jasa

Balas jasa/ kompensasi dapat berupa gaji dan kesejahteraan juga mempengaruhi kedisiplinan karyawan karena gaji memberikan kepuasan dan kecintaan karyawan terhadap perusahaan atau pekerjaannya.

d) Keadilan

Keadilan juga mendorong terwujudnya disiplin karyawan, karena ego dan fitrah manusia selalu dianggap penting, ingin agar dirinya diperhatikan oleh orang lain. Sebagai dasar kebijaksanaan dalam pengakuan atau hukuman, keadilan akan mendorong disiplin yang berjalan lancar.

e) Waskat

Waskat (pengawasan melekat) adalah tindakan yang nyata serta efektif dalam mewujudkan disiplin karyawan, karena dengan adanya waskat berarti pimpinan turut aktif dan langsung mengawasi perilaku, moral, sikap, semangat kerja, serta prestasi kerja bawahan.

f) Sanksi hukuman

Sanksi hukuman memiliki peran yang besar dalam memelihara tingkat disiplin karyawan. Dengan adanya sanksi yang semakin berat, maka karyawan akan semakin takut melanggar aturan yang ada didalam perusahaan, serta mampu mengurangi perilaku indisipliner karyawan.

g) Ketegasan

Bilamana pimpinan bersikap tegas dalam melakukan tindakan, maka akan mempengaruhi kedisiplinan karyawan. Pimpinan harus tegas bertindak dalam menghukum karyawan yang indisipliner sesuai dengan yang hukum yang berlaku.

h) Hubungan kemanusiaan

Hubungan antar manusia yang harmonis antar karyawan berkontribusi pada disiplin yang baik dalam sebuah perusahaan. Hubungan-hubungan itu baik bersifat vertikal maupun horizontal yang terdiri dari single relationship, direct group relationship, dan cross relationship; dimana ketiganya diharapkan dapat harmonis.

\subsection{Kinerja Pegawai}

Istilah kinerja berasal dari kata job perfomance atau actual perfomance prestasi kerja atau prestasi sesungguhnya yang dicapai oleh seseorang. Menurut Mangkunegara (2007, h. 67) pengertian dari kinerja adalah "Hasil kerja secara kualitas dan kuantitas yang dicapai oleh seorang pegawai dalam melaksanakan tugasnya sesuai dengan tanggung jawab yang diberikan kepadanya". 
Kinerja menurut pendapat Hasibuan (2016, h. 94) adalah "Suatu hasil kerja yang dicapai seseorang dalam melaksanakan tugas-tugas yang dibebankan kepadanya yang didasarkan atas kecakapan, pengalaman, dan kesungguhan serta waktu". Sedangkan definisi kinerja pegawai menurut Mangkunegara (2007, h. 67), adalah "Hasil kerja secara kualitas dan kuantitas yang dicapai oleh seorang pegawai dalam melaksanakan tugasnya sesuai dengan tanggung jawab yang diberikan kepadanya". Kemudian Moeheriono (2012, h. 60) menyatakan bahwa "Kinerja merupakan gambaran mengenai tingkat pencapaian pelaksanaan suatu program kegiatan atau kebijakan dalam mewujudkan sasaran, tujuan, visi dan misi organisasi yang dituangkan melalui perencanaan strategis suatu organisasi”.

Menurut Setiawan \& Kartika (2014, h. 1477) salah satu indikator yang dapat dijadikan gambaran kinerja seorang pegawai, yaitu sebagai berikut:

a) Ketepatan penyelesaian tugas, yaitu pengelolaan waktu dalam bekerja dan juga ketepatan karyawan dalam menyelesaikan pekerjaan;

b) Kesesuaian jam kerja, yaitu kesediaan karyawan dalam mematuhi peraturan perusahaan yang berkaitan dengan ketepatan waktu masuk/ pulang kerja dan jumlah kehadiran;

c) Tingkat kehadiran, dapat dilihat dari jumlah ketidakhadiran karyawan dalam suatu perusahaan selama periode tertentu;

d) Kerjasama antar karyawan, yaitu kemampuan karyawan untuk bekerja sama dengan orang lain dalam menyelesaikan suatu tugas yang ditentukan, sehingga mencapai daya guna dan hasil guna yang sebesar-besarnya; dan

e) Kepuasan kerja, yaitu karyawan merasa puas dengan jenis pekerjaan yang diberikan oleh perusahaan.

\section{Metode Penelitian}

Berdasarkan tujuan penelitian yang telah ditetapkan, maka jenis penelitian ini termasuk dalam jenis penelitian eksplanatori dengan menggunakan pendekatan kuantitatif deskriptif. Lokasi penelitian dilakukan di Bagian Umum dan Hukum Tata Laksana Universitas Brawijaya.

Penelitian ini menggunakan Teori Hasibuan (2016, h. 83), sementara terkait indikator pengembangan sumber daya manusia \& indikator disiplin kerja, serta teori, maka bersumber dari Setiawan, dkk (2014, h. 1477). Adapun mengenai indikator kinerja pegawai yang telah dilakukan modifikasi sesuai kebutuhan penelitian seperti terlihat pada Gambar 1 dibawah.

Adapun teknik pengumpulan data yang digunakan oleh peneliti, yaitu menggunakan metode survei dengan instrumen kuesioner. Metode pengambilan sampel yang digunakan adalah metode non-probability sampling, adapun teknik sampling yang digunakan adalah judgment sampling, yaitu teknik purposive sampling dengan kriteria berupa suatu pertimbangan tertentu (Hartono \& Abdillah 2009, h. 79). Dalam penelitian ini kriteria sampel yang ditetapkan adalah merupakan pegawai Non-PNS dan pegawai kontrak yang ada pada Bagian Umum dan Hukum Tata Laksana Universitas Brawijaya. Jumlah sampel adalah sebanyak 77 pegawai yang akan dijadikan sampel penelitian.

Metode penskalaan yang digunakan dalam mengukur variabel adalah menggunakan skala likert modifikasi dengan interval 1 sampai dengan 4 (Gambar 2).

Variabel yang digunakan dalam penelitian ini, yaitu sebagai berikut:

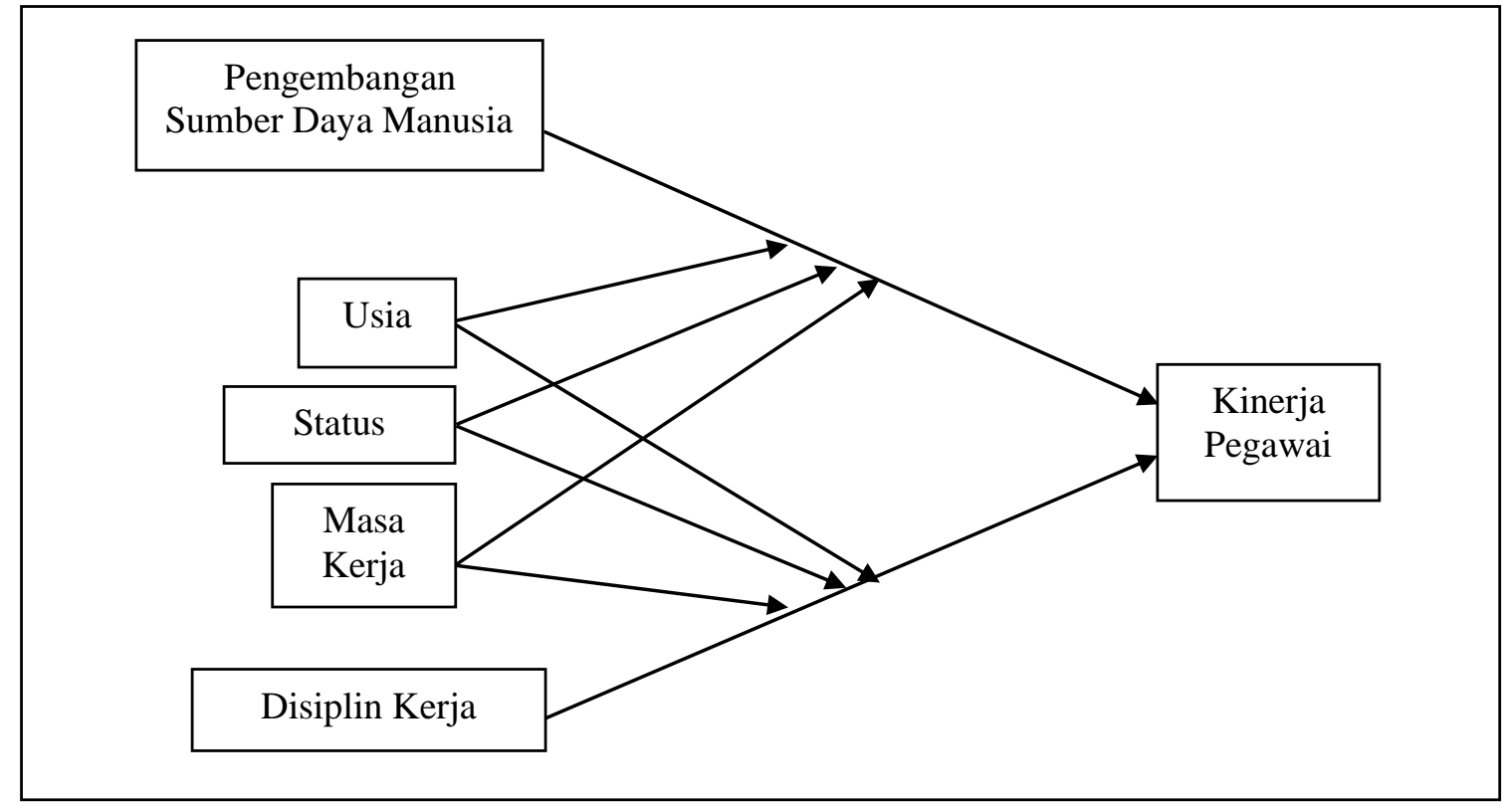

Gambar 1 Kerangka Konseptual Penelitian

Sumber: Faisal, 2007 
a) Variabel independen (X), yaitu pengembangan sumber daya manusia (X1), dan disiplin kerja (X2);

b) Variabel dependen (Y), yaitu kinerja pegawai (Y1); dan

c) Variabel moderasi (M), yaitu usia, status kerja, dan masa kerja.

Model analisis data yang digunakan untuk membuktikan hipotesis yang diajukan dalam penelitian ini adalah SEM (Structural Equation Modeling) dengan pendekatan PLS (Partial Least Square). PLS adalah Struktural Equation Modeling (SEM) yang berbasis komponen atau varian (variance).

Pengujian hipotesis dalam penelitian ini menggunakan Metode PLS, dengan bantuan Software SmartPLS 3.2.9. Ada dua hal yang harus dilakukan dalam menganalisis dengan menggunakan PLS. Pertama, menilai outer model atau measurement model, yaitu penilaian terhadap reliabilitas dan validitas variabel penelitian. Ada tiga kriteria untuk menilai outer model, yaitu convergent validity, discriminant validity, dan composite reliability. Kedua, menilai inner model atau structural model. Pengujian inner model atau model struktural dilakukan untuk melihat hubungan antara konstruk, nilai signifikansi, dan $R$-square dari model penelitian (Faisal, 2007, h. 15).
Composite Reliability seluruh konstruk yang digunakan adalah lebih dari 0.7, yang artinya adalah seluruh variabel konstruknya mempunyai reabilitas yang tinggi.

Variabel akan dianggap reliable apabila nilai korelasinya di atas 0,60 (Ghozali, 2006). Sehingga dapat dinyatakan bahwa semua variabel penelitian adalah reliabel.

Tabel 1 Output Algoritma SmartPLS 3.2.9

\begin{tabular}{|l|c|c|c|c|}
\hline \multicolumn{1}{|c|}{ Variabel } & AVE & $\begin{array}{c}\text { Composite } \\
\text { Reliability }\end{array}$ & $\begin{array}{c}\mathrm{R} \\
\text { Square } \\
\left(\mathrm{R}^{2}\right)\end{array}$ & Keterangan \\
\hline Usia (U) & 1.000 & 1.000 & & Reliabel \\
\hline $\begin{array}{l}\text { Status Kerja } \\
(\mathrm{SK})\end{array}$ & 1.000 & 1.000 & & Reliabel \\
\hline $\begin{array}{l}\text { Masa Kerja } \\
\text { (MK) }\end{array}$ & 1.000 & 1.000 & & Reliabel \\
\hline U*SK & 1.000 & 1.000 & & Reliabel \\
\hline $\mathrm{U}^{*} \mathrm{MK}$ & 1.000 & 1.000 & & Reliabel \\
\hline SK*MK & 1.000 & 1.000 & & Reliabel \\
\hline U*SK*MK & 1.000 & 1.000 & & Reliabel \\
\hline $\begin{array}{l}\text { Pengembangan } \\
\text { sumber daya } \\
\text { manusia (X })\end{array}$ & 0.522 & 0.865 & & Reliabel \\
\hline $\begin{array}{l}\text { Disiplin kerja } \\
\left(\mathrm{X}_{2}\right)\end{array}$ & 0.509 & 0.838 & & Reliabel \\
\hline $\begin{array}{l}\text { Kinerja } \\
\text { pegawai (Y } 1)\end{array}$ & 0.563 & 0.835 & 0.375 & Reliabel \\
\hline
\end{tabular}

Sumber: Hasil analisis, 2020

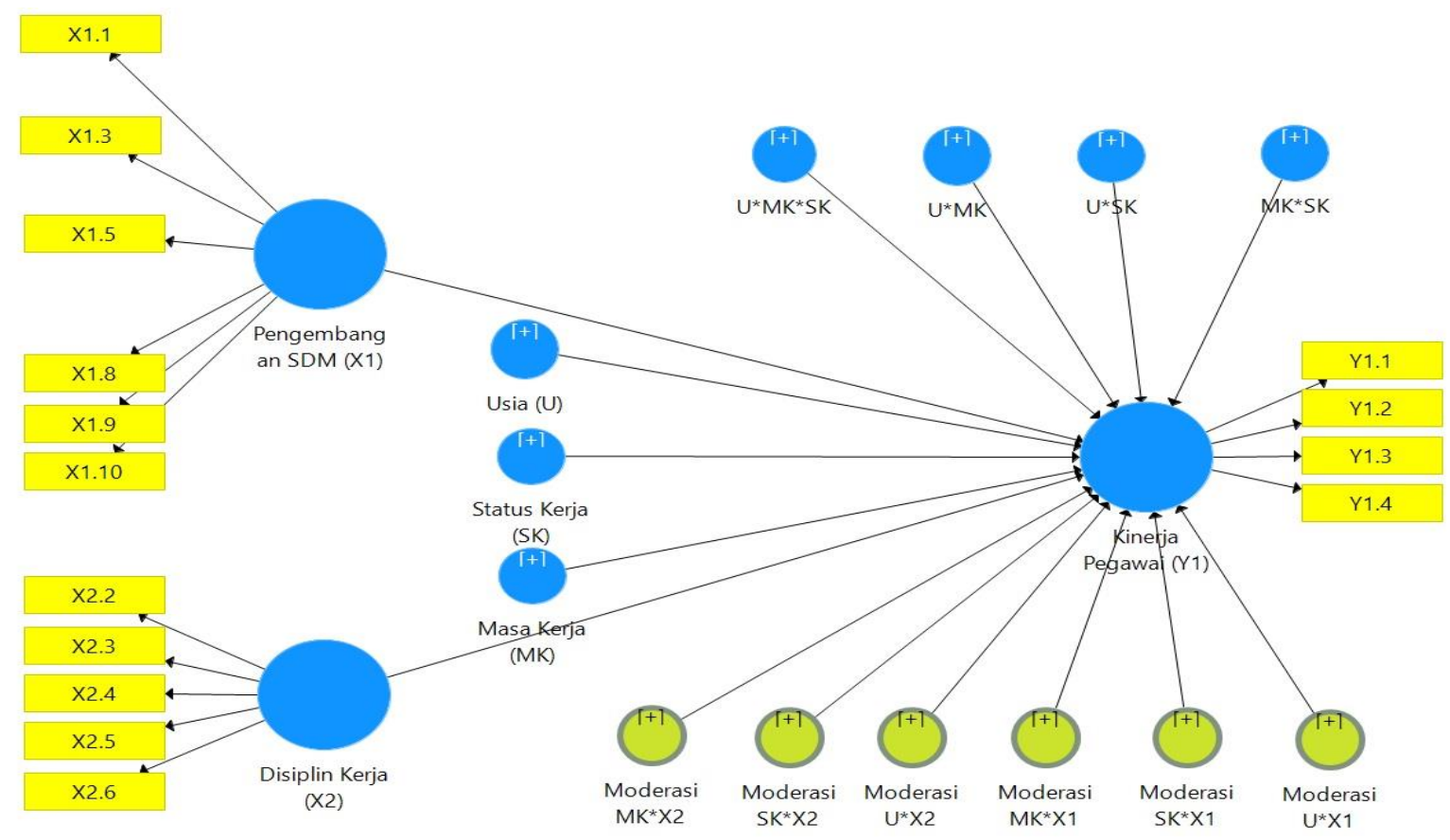

Gambar 2 Kerangka Konseptual

Sumber: Hasil analisis, 2020

\section{Hasil Penelitian dan Pembahasan}

Dari hasil pengujian reabilitas algoritma SmartPLS 3.2.9 dengan dasar nilai AVE (Average Variance Extracted) dan Composite Reliability pada tabel 4.1, maka diketahui bahwa nilai AVE seluruh konstruk yang digunakan adalah lebih dari 0,50 dan untuk nilai
Hasil pengujian Goodness of Fit dapat dilihat dalam tabel berikut ini:

Tabel 2 Output Algoritma Pengujian Goodness of Fit

\begin{tabular}{|c|c|}
\hline Variabel Endogen & R Square $\left(\mathrm{R}^{2}\right)$ \\
\hline Kinerja pegawai $\left(\mathrm{Y}_{1}\right)$ & 0.375 \\
\hline
\end{tabular}

Sumber: Hasil analisis, 2020 
Berdasarkan hasil pengujian Goodness of Fit pada Tabel 2 diperoleh bahwa nilai R-square (R2) untuk variabel endogen Kinerja pegawai (Y1) sebesar 0,375 atau $37,5 \%$.

Perhitungan Q-square (Q2) dengan menggunakan data R-square (R2) yang ada pada dua R2 di tabel 2 dapat dilakukan sebagai berikut:

$$
\begin{aligned}
& \mathrm{Q}^{2}=1-\left(1-\mathrm{R}_{1}{ }^{2}\right) \\
& \mathrm{Q}^{2}=1-(\sqrt{1-0,375}) \\
& \mathrm{Q}^{2}=1-(\sqrt{0,625} \\
& \mathrm{Q}^{2}=1-(0,790) \\
& \mathrm{Q}^{2}=0,210
\end{aligned}
$$

Berdasarkan perhitungan Q-square (Q2) di atas, maka diperoleh nilai $\mathrm{Q}$-square $(\mathrm{Q} 2)$ sebesar 0,210 > 0 . Angka tersebut dapat diinterpretasikan bahwa model penelitian yang telah dilakukan dapat menjelaskan $21 \%$ informasi yang terkandung di dalam data sebesar $21 \%$, model yang telah dilakukan mempunyai nilai predictive relevance atau tingkat prediksinya yang cukup akurat.

Ringkasan hasil uji hipotesis tanpa pengaruh efek moderasi dan hasil uji hipotesis dengan pengaruh efek moderasi dapat dilihat pada tabel berikut ini:

Tabel 3 Ringkasan Hasil Uji Hipotesis

\begin{tabular}{|l|c|c|l|l|l|}
\hline Hipotesis & Independen & Dependen & Moderasi & Nilai t & Keterangan \\
\hline H1 & $\mathrm{X}_{1}$ & $\mathrm{Y}_{1}$ & - & 1.706 & Ditolak \\
\hline H1a & $\mathrm{X}_{1}$ & $\mathrm{Y}_{1}$ & Usia & 0.063 & Ditolak \\
\hline H1b & $\mathrm{X}_{1}$ & $\mathrm{Y}_{1}$ & $\begin{array}{l}\text { Status } \\
\text { Kerja }\end{array}$ & 0.409 & Ditolak \\
\hline H1c & $\mathrm{X}_{1}$ & $\mathrm{Y}_{1}$ & $\begin{array}{l}\text { Masa } \\
\text { Kerja }\end{array}$ & 0.007 & Ditolak \\
\hline H2 & $\mathrm{X}_{2}$ & $\mathrm{Y}_{1}$ & - & 2.643 & Diterima \\
\hline H2a & $\mathrm{X}_{2}$ & $\mathrm{Y}_{1}$ & Usia & 0.409 & Ditolak \\
\hline $\mathrm{H} 2 \mathrm{~b}$ & $\mathrm{X}_{2}$ & $\mathrm{Y}_{1}$ & $\begin{array}{l}\text { Status } \\
\text { Kerja }\end{array}$ & 0.344 & Ditolak \\
\hline H2c & $\mathrm{X}_{2}$ & $\mathrm{Y}_{1}$ & $\begin{array}{l}\text { Masa } \\
\text { Kerja }\end{array}$ & 0.557 & Ditolak \\
\hline
\end{tabular}

Sumber: Hasil analisis, 2020

Hasil pengujian variabel pengembangan sumber daya manusia (X1) dengan variabel kinerja pegawai (Y1) menunjukkan pengaruh positif akan tetapi tidak signifikan, hal ini dapat dilihat dari koefisien regresinya (original sample) sebesar 0.326 dan t-hitung (t-statistik) sebesar $1.706(<1.96)$ yang lebih kecil dibandingkan dengan nilai t-tabel.

Hasil pengujian variabel disiplin kerja (X2) dengan variabel kinerja pegawai (Y1) menunjukkan pengaruh positif dan signifikan, hal ini dapat dilihat dari koefisien regresinya (original sample) sebesar 0.190 dan t-hitung (t-statistik) sebesar 2.643 (>1.96) yang lebih besar dibandingkan dengan nilai t-tabel.

Usia, status kerja, dan masa kerja tidak memoderasi dalam pengaruh pengembangan sumber daya manusia dan disiplin kerja terhadap kinerja pegawai.

\section{Kesimpulan}

Berdasarkan dari hasil pengujian hipotesis dan pembahasan hasil penelitian, dapat disimpulkan antara lain sebagai berikut:

a) Berdasarkan hasil pengujian hipotesis dapat diperoleh bukti empiris bahwa $\mathrm{H} 1$ tidak didukung, meskipun dari hasil pengujian variabel menyatakan bahwa pengembangan sumber daya manusia terhadap variabel kinerja pegawai menunjukkan pengaruh positif akan tetapi tidak signifikan. Hal ini dapat dilihat dari koefisien regresinya sebesar 0.326 dan t-statistik sebesar $1.706(<1.96)$ yang lebih kecil dibandingkan dengan nilai t-tabel; dan

b) Hasil dari pengujian hipotesis memperoleh bukti empiris bahwa $\mathrm{H} 2$ didukung dengan koefisien positif. Selain itu hasil pengujian pada variabel disiplin kerja terhadap variabel kinerja pegawai menunjukkan pengaruh positif dan signifikan. Hal ini dapat dilihat dari koefisien regresinya sebesar 0.190 dan t-statistik sebesar 2.643 (>1.96) yang lebih besar dibandingkan dengan nilai t-tabel. Artinya, adalah semakin tinggi disiplin kerja maka semakin tinggi pula kinerja pegawai. Hasil penelitian ini dikuatkan dengan hasil penelitian terdahulu yang telah dilakukan oleh Hasibuan (2016, h. 193) dan Rivai (2008, h. 824).

\section{Daftar Pustaka}

Faisal. (2007). Analisis Pengaruh Intensitas Persaingan Dan Variabel Kontekstual Terhadap Penggunaan Informasi Sistem Akuntansi Manajemen dan Kinerja Unit Bisnis Dengan Pendekatan Partial Least Square. The Indonesian Journal of Accounting Research (IJAR), 10(2), 12-20. DOI: http://doi.org/10.33312/ijar.172

Ghozali, I. (2008). Structural Equation Modeling: Metode Alternatif dengan Partial Least Square PLS. Semarang: Badan Penerbit - UNDIP.

Hartono, M.J., \& Abdillah, W. (2009). Konsep dan Aplikasi PLS Untuk Penelitian Empiris. Yogyakarta: BPFE.

Hasibuan, Malayu S.P. (2016). Manajemen Sumber Daya Manusia. Edisi Revisi. Jakarta: PT Bumi Aksara.

Mangkunegara, A. A. Anwar Prabu. (2007). Manajemen Sumber Daya Manusia Perusahaan. Bandung: PT. Remaja Rosda Karya.

Mathis, Robert L., \& Jackson, John H. (2006). Human Resource Management: Manajemen Sumber Daya Manusia (Terjemahan oleh Dian Angelia). Jakarta: Salemba Empat.

Moeheriono. (2012). Pengukuran Kinerja Berbasis Kompetensi - Edisi Revisi. Jakarta: PT. Raja Grafindo Persada. 
Ndraha, Taliziduhu. (1999). Pengantar Teori Pengembangan Sumber Daya Manusia. Jakarta: Rineka Cipta.

Rivai, Veithzal. (2008). Manajemen Sumber Daya Manusia Untuk Perusahaan: dari Teori dan Praktik. Jakarta: PT. Raja Grafindo Persada.

Rowley, Chris \& Jackson, Keith. (2012). Manajemen Sumber Daya Manusia: The Key Concepts (Cetakan Kesatu). Jakarta: PT. Raja Grafindo Persada.

Sastrohadiwiryo, Siswanto. (2003). Manajemen Tenaga Kerja Indonesia, Pendekatan Administrasi dan Operasional. Jakarta: Bumi Aksara.

Setiawan, Ferry., \& Dewi, Kartika. (2014). Pengaruh Kompensasi Dan Lingkungan Kerja Terhadap Kinerja Karyawan pada CV. Berkat Anugrah. EJurnal Manajemen, 3(5), 1471-1490. Diakses dari https://ojs.unud.ac.id/index.php/Manajemen/articl e/view/7951

Siagian, Sondang P. (2006). Manajemen Sumber Daya Manusia. Jakarta: Bumi Aksara.

Sinambela, L.P. (2014). Metode Penelitian Kuantitatif; Untuk Bidang Ilmu Administrasi, Kebijakan Publik, Ekonomi, Sosiologi, Komunikasi dan Ilmu Sosial Lainnya. Yogyakarta: Graha Ilmu. 